\title{
EOSINOPHILIC VARIANT OF CLEAR CELL RENAL CELL CARCINOMA - A DIAGNOSTIC DILEMMA
}

\author{
NAMRATA RAO ${ }^{1 *}$, VIDYA MONAPPA ${ }^{2}$, SUMAN K
}

${ }^{1}$ Department of Pathology, Melaka Manipal Medical College, Manipal Academy of Higher Education, Manipal, Karnataka, India. ${ }^{2}$ Department of Pathology, Kasturba Medical College, Manipal Academy of Higher Education, Manipal - 576 104, Karnataka, India. Email: doctornamrata2411@gmail.com

Received: 24 September 2018, Revised and Accepted: 02 November 2018

ABSTRACT

Case Report: Eosinophilic variant of clear cell renal cell carcinoma is an important entity to diagnose since it is aggressive and is associated with poor prognosis.

A 75-year-old patient presented with pain abdomen. The magnetic resonance imaging showed a mass in the kidney. The differential diagnosis given was renal cell carcinoma and hydatid cyst. Nephrectomy was done and the specimen was sent for histopathology. The specimen showed a gray-brown lesion with extensive areas of hemorrhage and necrosis. On microscopy, the tumor cells were arranged in nests. The cells had abundant eosinophilic granular cytoplasm. The differential diagnosis on morphology was chromophobe renal cell carcinoma and oncocytoma with extensive inflammation. However, immunohistochemistry (IHC) proved the diagnosis of eosinophilic variant of clear cell renal cell carcinoma.

Conclusion: Hence, IHC is an essential adjunct to morphology in diagnosing renal neoplasms.

Keywords: Eosinophilic, Immunohistochemistry, Renal, Carcinoma, Clear.

(C) 2019 The Authors. Published by Innovare Academic Sciences Pvt Ltd. This is an open access article under the CC BY license (http://creativecommons. org/licenses/by/4. 0/) DOI: http://dx.doi.org/10.22159/ajpcr.2019.v12i2.29188

\section{INTRODUCTION}

Clear cell renal cell carcinomas are the most common type of renal carcinomas with a peak incidence in the sixth-seventh decade [1]. They show a male preponderance. They generally carry a worse prognosis as compared to the other types [2]. The eosinophilic variant has the same molecular characteristics as the conventional clear cell renal cell carcinoma [3]. The eosinophilic variant differs from the conventional type in having cells with abundant eosinophilic cytoplasm. The diagnosis of this entity is challenging since it may mimic other eosinophilic neoplasms of the kidney. In such cases, immunohistochemistry (IHC) plays a pivotal role in arriving at the diagnosis. The importance of recognizing this variant is that these tumors are more aggressive and are associated with a higher grade, stage, and a poor prognosis. Eosinophilic component greater than $50 \%$ may predict a poor response to interleukin 2 therapy [4].

\section{CASE REPORT}

A 75-year-old male patient presented with pain abdomen for 15 days. The magnetic resonance imaging of the abdomen showed a mass in the kidney. The differential diagnosis given on radiology was renal cell carcinoma and hydatid cyst. Nephrectomy was done and the specimen was sent for histopathological examination. The specimen measured $21 \mathrm{~cm} \times$ $11.5 \mathrm{~cm} \times 10 \mathrm{~cm}$. Cut surface showed an ill circumscribed solid cystic graybrown lesion with extensive areas of hemorrhage and necrosis located at the upper pole of the kidney measuring $15 \mathrm{~cm} \times 10.5 \mathrm{~cm} \times 7 \mathrm{~cm}$. Adjacent area showed normal renal parenchyma. Attached ureter and vessels were identified. Sections were submitted as per the protocol for malignant tumors. Sections from thelesion showed sheets of cyst macrophages, mixed inflammatory infiltrate, cholesterol clefts, numerous multinucleated giant cells, hemosiderin-laden macrophages, and extensive areas of hemorrhage and necrosis (Fig. 1). Few tissue fragments showed cells arranged in nests, acinar pattern, and alveolar clusters. The cells were round to polygonal with abundant eosinophilic granular cytoplasm having moderate-sized round to oval nucleus with some showing inconspicuous basophilic nucleoli (Fig. 2). The nests of cells were surrounded by delicate blood vessels. On morphology, the differential diagnosis included oncocytoma with extensive inflammation and eosinophilic variant of chromophobe renal cell carcinoma. Hale's colloidal iron was negative, which favored a diagnosis of oncocytoma with concurrent inflammation (Fig. 3). However, a panel of IHC was requested to confirm the diagnosis. The IHC report proved both the differential diagnoses to be wrong. The tumor cells were Vimentin, CD 10 positive, and CK 7, CD 117, and S 100 negative (Figs. 4-6). This favored the diagnosis of clear cell carcinoma-eosinophilic variant. Following this, extensive sampling of the tumor was done. One focus of cells having conventional clear cell carcinoma morphology was identified (Fig. 7).

\section{DISCUSSION}

The prognosis of each type of renal cell carcinoma varies [5]. Hence, it is important to classify these tumors. Earlier the diagnosis was solely based on morphology. With the advent of IHC, its role in diagnosing tumors cannot be overemphasized. IHC plays a pivotal role in the diagnosis of

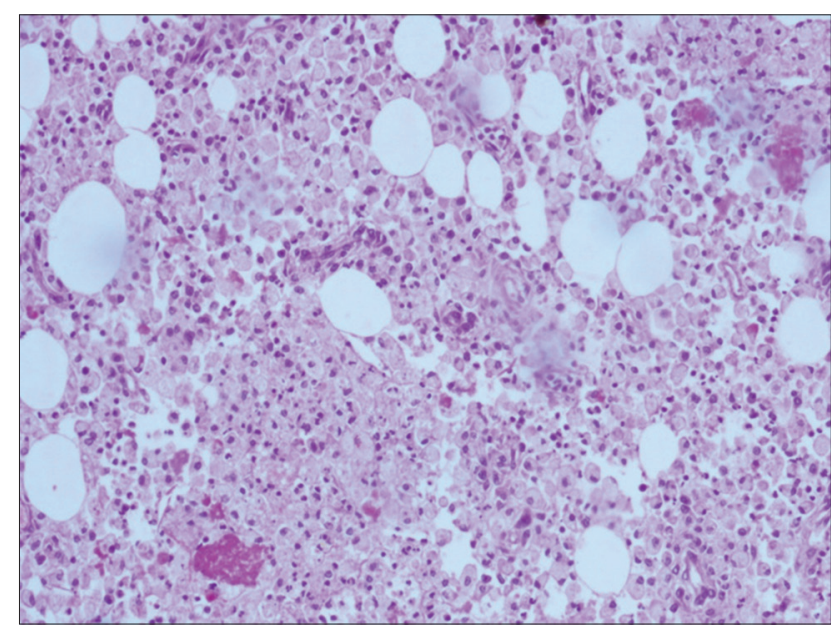

Fig. 1: Sheets of cyst macrophages and mixed inflammatory cells (Hematoxylin and Eosin, $\times 100$ ) 


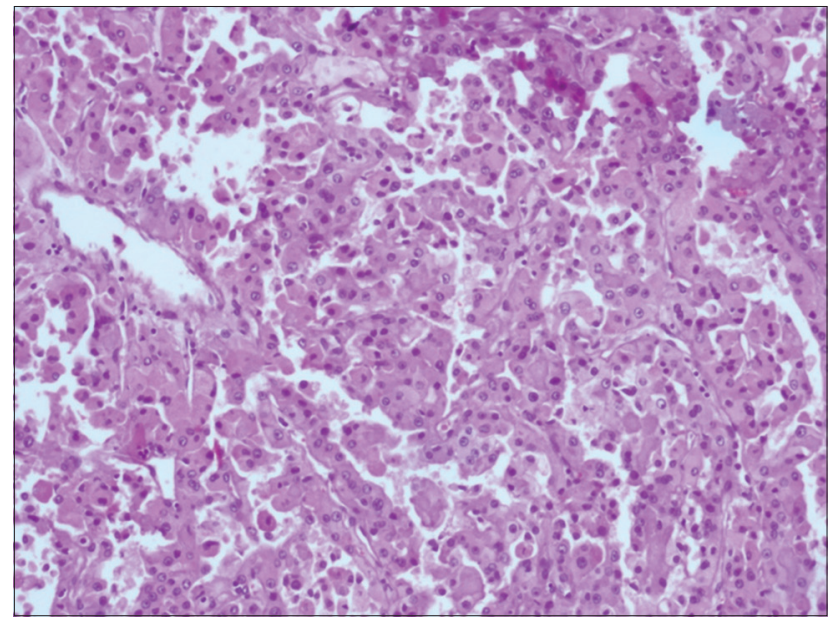

Fig. 2: Tumor cells having abundant eosinophilic cytoplasm (Hematoxylin and Eosin, $\times 100$ )

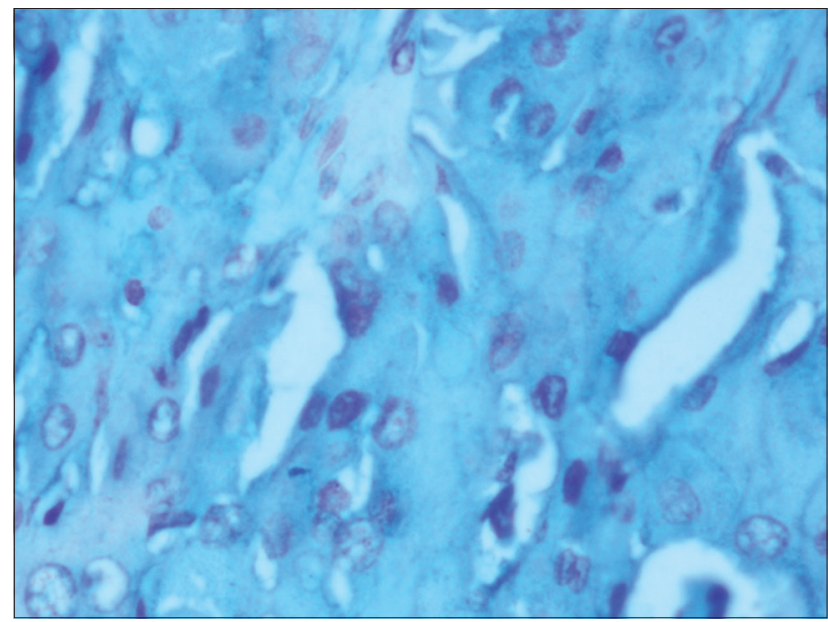

Fig. 3: Tumor cells are colloidal iron negative (Colloidal iron, $\times \mathbf{4 0 0}$ )

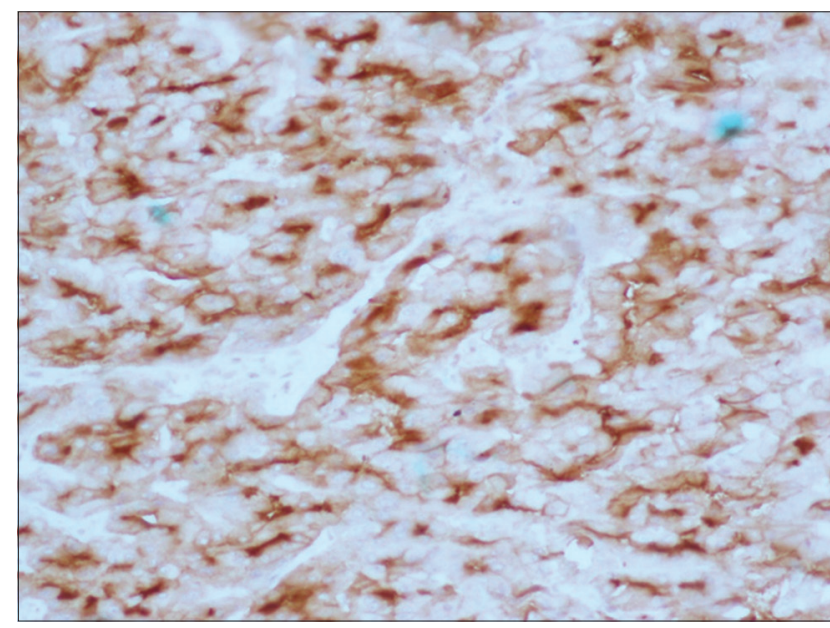

Fig. 4: Tumor cells are CD10 positive $(C D 10, \times 100)$

renal carcinomas. Although the morphology hints toward the diagnosis, IHC is essential for confirming the same. In our case too, on morphology oncocytoma and chromophobe type were considered since these tumors commonly have abundant eosinophilic cytoplasm. However, it was the IHC which proved that the diagnosis was a clear cell carcinoma. Eosinophilic variant of clear cell carcinoma previously called granular

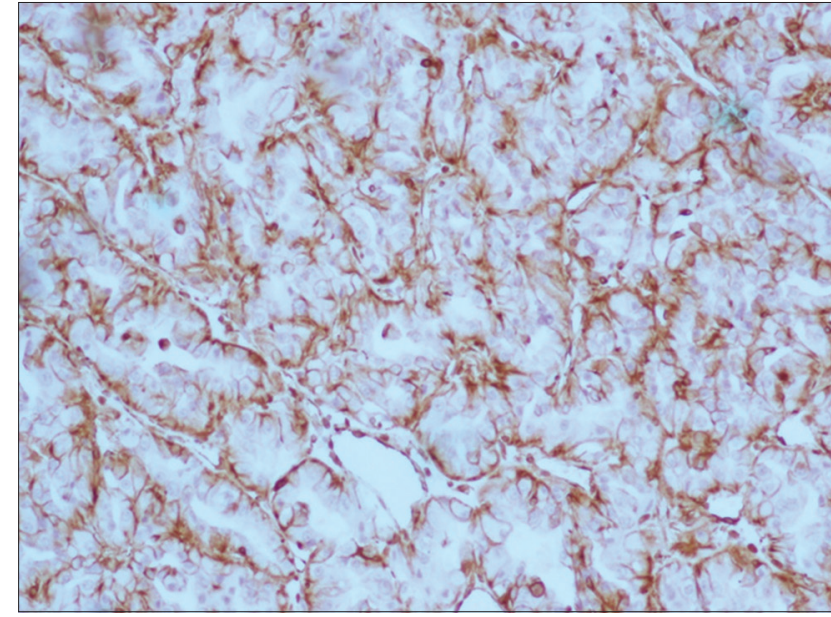

Fig. 5: Tumor cells are vimentin positive (vimentin, $\times 100$ )

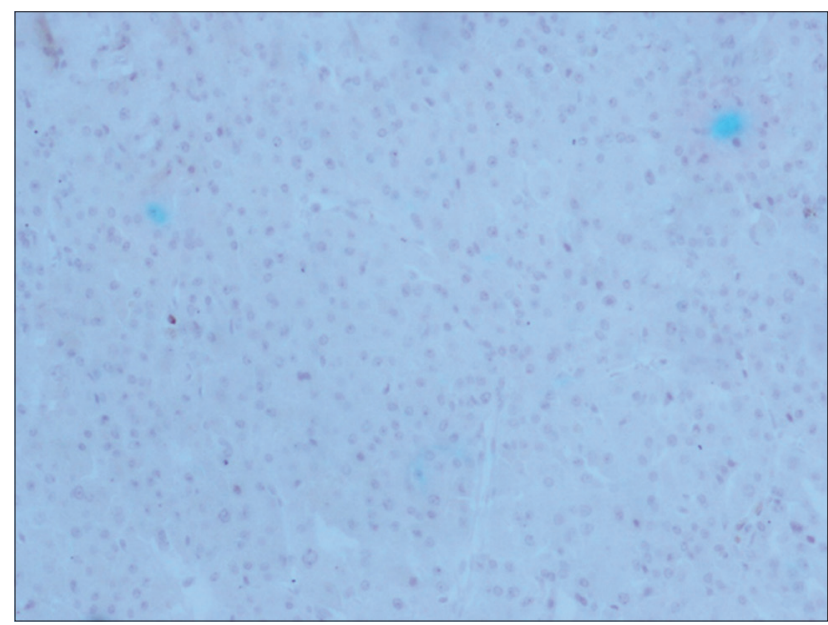

Fig. 6: Tumor cells are CD117 negative $(C D 117, \times 100)$

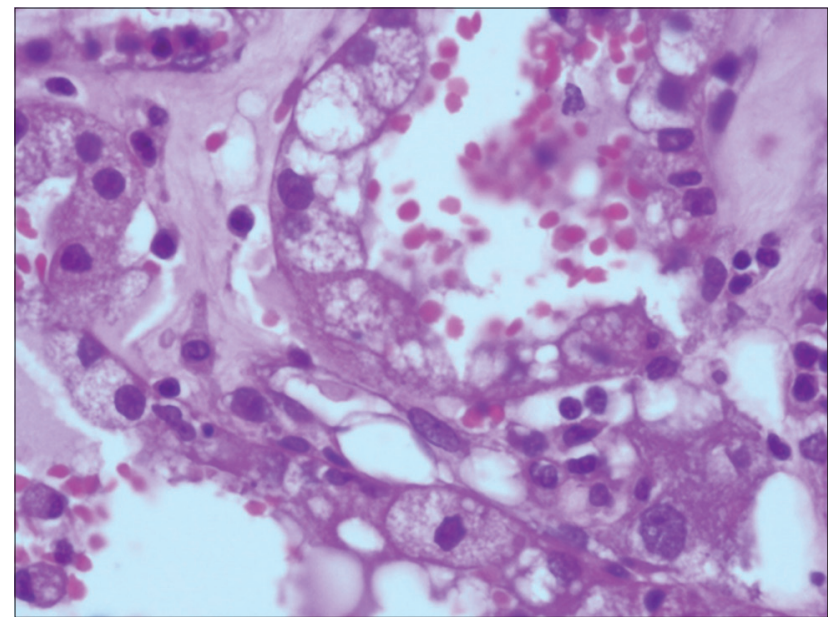

Fig. 7: Tumor cells showing the conventional clear cell morphology (Hematoxylin and Eosin, $\times 400$ )

variant of clear cell carcinoma is a rare tumor which can be confused with other eosinophilic neoplasms of the kidney. Chromophobe renal cell carcinoma, oncocytoma, and eosinophilic variant of clear cell carcinoma always pose a diagnostic challenge. CD 10 and CD 117 are useful markers to help in distinguishing the above. CD 10 favors eosinophilic variant of clear cell carcinoma and CD 117 favors the other two. The negative 
colloidal iron staining serves as a useful adjunct in diagnosis [6]. The eosinophilic variant is usually large on gross morphology with extensive areas of hemorrhage and necrosis [7]. Microscopically, the characteristic feature is the rich sinusoidal network around the nests of tumor cells [8]. This probably serves as a subtle clue to help in arriving at a diagnosis. The prognosis of this tumor is poor as compared to the conventional clear cell carcinoma. Hence, it is essential to identify this variant. The histological features in renal cell carcinoma have an impact on survival of the patient [9]. It is said that extensive sampling of the tumor may show foci of tumor having the conventional clear cell morphology, as in our case [10]. Cancers have now become a serious threat causing death in most countries [11]. They are a heterogeneous group, each having a varied response to treatment [12]. Importance lies in adequately subtyping a tumor to ensure responsiveness to therapy.

\section{CONCLUSION}

IHC is an important adjunct to morphology in classifying renal cell carcinomas. It is advisable to support the histopathological report with IHC to confirm the diagnosis. Since the prognosis of each type of renal cell carcinoma varies, it is vital to subtype these tumors and identify even the uncommon variants. The eosinophilic variant of clear cell carcinomas should be a differential diagnosis in addition to oncocytoma and chromophobe renal cell carcinomas in tumors having cells with abundant eosinophilic cytoplasm.

\section{AUTHORS' CONTRIBUTIONS}

Dr. Namrata Rao, Dr. Vidya Monappa, and Dr. K. Suman have contributed in the diagnosis of the case, write up of the case report and in the review of literature.

\section{CONFLICTS OF INTEREST}

The authors declare that they have no conflicts of interest.

\section{REFERENCES}

1. Zhou M, Netto GJ, Epstein JI. Neoplastic disease of the kidney. In: Zhou M, Netto GJ, Epstein JI, editors. Uropathology. Philadelphia, PA: Elsevier; 2012. p. 266-338.

2. Grignon DJ, Che M. Clear cell renal cell carcinoma. Clin Lab Med 2005; 25:305-16.

3. Yang XJ, Takahashi M, Schafernak KT, Tretiakova MS, Sugimura J, Vogelzang NJ, et al. Does 'granular cell' renal cell carcinoma exist? Molecular and histological reclassification. Histopathology 2007; 50:678-80

4. Upton MP, Parker RA, Youmans A, McDermott DF, Atkins MB. Histologic predictors of renal cell carcinoma response to interleukin-2based therapy. J Immunother 2005;28:488-95.

5. Geramizadeh B, Ravanshad M, Rahsaz M. Useful markers for differential diagnosis of oncocytoma, chromophobe renal cell carcinoma and conventional renal cell carcinoma. Indian J Pathol Microbiol 2008;51:167-71.

6. Wang HY, Mills SE. KIT and RCC are useful in distinguishing chromophobe renal cell carcinoma from the granular variant of clear cell renal cell carcinoma. Am J Surg Pathol 2005;29:640-6.

7. Kryvenko ON, Jorda M, Argani P, Epstein JI. Diagnostic approach to eosinophilic renal neoplasms. Arch Pathol Lab Med 2014;138:1531-41.

8. Kryvenko ON, Roquero L, Gupta NS, Lee MW, Epstein JI. Low-grade clear cell renal cell carcinoma mimicking hemangioma of the kidney: A series of 4 cases. Arch Pathol Lab Med 2013;137:251-4.

9. Kumar A. Finger metastases in renal cell carcinoma: A case report. Asian J Pharm Clin Res 2016;9:4-6.

10. Eosinophilic Variant of Clear Cell Renal Cell Carcinoma. Pathologyoutlines.com. Available from: http://www.pathologyoutlines. com/topic/kidneytumormalignantcelleosinophilic.html.

11. Deepika KS, Navya KR, Muthuraman MS, Natesan R, Raj CD, Pemaiah B. Evaluation of in vitro anticancer potential of ethanolic extract and its different fractions of Caesalpinia bonduc (L) roxb seeds. Int J Pharm Pharm Sci 2014;6:311-4.

12. Minakshi G, Dahiya J, Marwaha RK, Dureja H. Therapies in cancer treatment: An overview. Int J Pharm Pharm Sci 2015;7:1-9. 